\title{
THE ROLES OF MEDICAL DOCTOR AND FAMILY ON PATIENT HEALTH BEHAVIOR IN CONTROLLING HBA1C LEVEL AMONG PATIENTS WITH TYPE 2 DIABETES MELLITUS AT Dr. MOEWARDI HOSPITAL, SURAKARTA
}

\author{
Hosea Puspitasari Pranoto ${ }^{1)}$, Didik Tamtomo²), Bhisma Murti1) \\ 1)Masters Program in Public Health, Sebelas Maret University \\ 2)Masters Program in Family Medicine, Sebelas Maret University
}

\begin{abstract}
Background: Diabetes Mellitus is one of non-communicable diseases with high prevalence of complication and mortality at productive age. Patients with type $2 \mathrm{DM}$ need to control their blood glucose level to attain optimal blood glucose. Thereby, it is expected to prevent or minimize the incidence of complication. This study aimed to examine the roles of medical doctor and family on patient health behavior in controlling $\mathrm{HbA1C}$ level among patients with type 2 diabetes mellitus at Dr. Moewardi Hospital, Surakarta.

Subjects and Method: This was an analytic observational study with case control design. This study was conducted at Dr. Moewardi Hospital, Surakarta, from April to May, 2017. A sample of 50 patients with type 2 Diabetes Mellitus and 100 control group were selected by fixed disease sampling. The dependent variable was $\mathrm{HbA1C}$ blood level. The independent variables were roles of medical doctor, roles of family, treatment compliance, physical activity, diet, and duration of illness. HbA1C blood level was measured by clinical laboratory test. The independent variable was measured by a set of questionnaire. The data were analyzed by path analysis.

Results: HbA1C blood level was affected by duration of illness $(b=0.04 ; \mathrm{SE}=$ $0.01 ; \mathrm{p}<0.001)$, diet $(\mathrm{b}=0.18 ; \mathrm{SE}=0.09 ; \mathrm{p}=0.044)$, and physical activity $(\mathrm{b}=$ $0.16 ; \mathrm{SE}=0.07 ; \mathrm{p}=0.024)$. Diet was affected by the role of medical doctor $(b=$ $0.02 ; \mathrm{SE}=0.07 ; \mathrm{p}=0.766)$, the role of family $(b=0.13 ; \mathrm{SE}=0.07 ; \mathrm{p}=0.082)$, duration of illness $(b=0.01 ; \mathrm{SE}=0.01 ; \mathrm{p}=0.063)$, and treatment compliance $(\mathrm{b}=0.32 ; \mathrm{SE}=0.11 ; \mathrm{p}=0.002)$. Physical activity was affected by the role of medical doctor $(b=0.17 ; \mathrm{SE}=0.08 ; \mathrm{p}=0.025)$, the role of family $(\mathrm{b}=0.21 ; \mathrm{SE}=$ $0.09 ; \mathrm{p}=0.017)$, diet $(\mathrm{b}=0.27 ; \mathrm{SE}=0.10 ; \mathrm{p}=0.005)$ and duration of illness $(\mathrm{b}=0.03 ; \mathrm{SE}=0.01 ; \mathrm{p}<0.001)$. Treatment compliance was affected by the role of medical doctor $(b=0.18 ; \mathrm{SE}=0.05 ; \mathrm{p}<0.001)$ and the role of family $(b=$ $0.24 ; \mathrm{SE}=0.05 ; \mathrm{p}<0.001$ ).

Conclusion: $\mathrm{HbA1C}$ blood level was directly affected by duration of illness, diet, and physical activity. $\mathrm{HbA} 1 \mathrm{C}$ blood level was indirectly affected by the role of medical doctor, the role of family, duration of illness, and treatment compliance, and diet.
\end{abstract}

Keywords: HbA1C level, diabetes mellitus, healthy behavior

Correspondence: Hosea Puspitasari Pranoto. Masters Program in Public Health, Sebelas Maret University, Surakarta.Email: hoseapuspita@gmail.com. Mobile: +6281804452941 . 